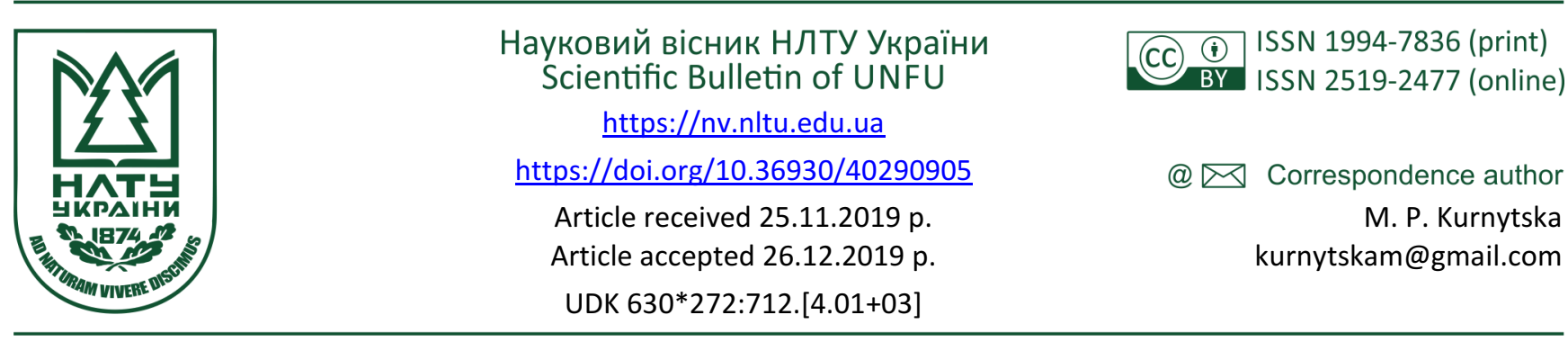

М. П. Курницька, Л. В. Пархуць, Н. Є. Горбенко

Національний лісотехнічний університет Украйни, м. Львів, Украӥна

\title{
ЛАНДШАФТНО-ІСТОРИЧНИЙ АНАЛІЗ ТЕРИТОРІЇ ПАРКУ У СМТ ПОМОРЯНИ
}

На підставі архівних документів проаналізовано генезис створення та формування парку біля замку в смт Поморяни на Львівщині. Узагальнено первісні особливості планувальної, просторової та функціональної структури території парку, подано стильову характеристику загальної композиції об'єкт. Встановлено трансформацію початкового пейзажного планування парку в регулярно-пейзажний стиль, який поєднував партерну частину перед центральним входом у будівлю 3 пластичними вигинами прогулянкових доріжок, що було характерним прийомом композиції маєтків того часу. З'ясовано, що планувальна структура об'єкта ні періоду закладання, ні періоду розквіту практично не збереглася. Виявлено залишки колишніх земляних укріплень та окремі фрагменти доріжок, які добре збереглися під гумусним нашаруванням. Простежено незначну подібність сучасної об'ємно-просторової структури насаджень деяким періодам функціонування об'єкта. Виявлено зростання близько 400 дерев, які представляють 15 видів 311 родів та 8 родин. Переважають у складі деревостану здебільшого вікові Tilia cordata Mill., Fraxinus excelsior L., та Acer platanoides L., які, ймовірно, були основою паркових насаджень у часи його закладання. 3 цієї причини більшість дерев $(74,4 \%)$ мають задовільний стан. Серед багатовікових виявлено два величні дерева-довгожителі з відповідною історичною та науковою цінністю, тому потребують відповідного охоронного статусу. Узагальнено наявні проблеми та важливість подальших різнобічних досліджень замкової території для розроблення проектів іiї реконструкції.

Ключові слова: призамкова територія; композиція; дендрофлора; вікова структура.

Вступ. Занедбані замки, маєтки чи резиденції з прилеглими до них територіями у сучасній Україні, на жаль, звичне явище. Історія кожного такого об'єкта має свої трагічні сторінки. Але неприпустимо прикрим фактом стає руйнація цінної споруди уже в теперішній час, на наших очах, коли, здавалось би, є розуміння, увага, свідомість та й певні економічні передумови до ії запобігання. Така доля замку в смт Поморяни Золочівського району. 3 плином часу незворотних змін зазнав і парк біля замку, в якому повністю втрачений композиційний задум, деградували зелені насадження. Проте у цього об'єкта є перспектива відновлення, тому різнобічний ландшафтний аналіз призамкової території $є$ важливим і необхідним для планування майбутніх реконструктивних і реставраційних робіт.

Аналіз літературних джерел. Тематика досліджень палацово-паркових комплексів $є$ досить широкою і популярною серед науковців цього спрямування. Архітектурні і ландшафтні аналізи історичних палацово-паркових об'єктів здійснювали такі відомі вчені, як О. Липа, І. Д. Родічкін, В. А. Горохов, Л. І. Рубцов, І.О.Косаревський. Дослідження сучасного стану дендрофлори історичних парків та розробку основних напрямків іiї збереження і відновлення знаходимо в працях українських та зарубіжних вчених (Sosnova, 2003; Moroz, 2006; Orlovskyi, 2006; Michałowski, 2010; Mitkowska, 2012; Ławniczak, 2014; Denysova, 2015). Вони відзначають руйнівні зміни та різні стадії деградації архітектурних і ландшафтних елементів досліджуваних об'єктів, спричинені як природними, так і антропогенними факторами. Негативна трансформація особливо помітна у паркових насадженнях, які, будучи культурфітоценозами, не можуть існувати і правильно розвиватися без постійного догляду і формування. Як наслідок, відбуваються кардинальні зміни у просторовій, видовій, віковій структурі фітоценозів таких парків аж до зміни типу ландшафту і повної втрати естетичної привабливості.

Як зазначає Ю. О. Кузнєцов (Klymenko \& Kuznietsov, 2015), проблеми відновлення історичних парків мають включати історичний, біологічний та соціальний особливості.

Об'єкт дослідження - паркова територія занедбаного замку XVI-XVII ст. у смт Поморяни Золочівського району Львівської області.

Предмет дослідження - методи визначення ландшафтної, планувальної, просторової та дендрологічної структури парку від часу його закладання до сьогодення.

\section{Інформація про авторів:}

Курницька Марта Петрівна, канд. с.-г. наук, доцент, кафедра ландшафтної архітектури, садово-паркового господарства та урбоекологіï. Email: kurnytskam@gmail.com; https://orcid.org/0000-0003-1059-9857

Пархуць Любомир Васильович, ст. викладач, кафедра ландшафтної архітектури, садово-паркового господарства та урбоекологіï. Email: lubom.pa@gmail.com

Горбенко Наталія Євгенівна, канд. с.-г. наук, доцент, кафедра деревинознавства та недеревних ресурсів лісу. Email: nata.horbenko@gmail.com

Цитування за ДСту: Курницька М. П., Пархуць Л. В., Горбенко Н. Є. Ландшафтно-історичний аналіз території парку у смт Поморяни. Науковий вісник НЛТУ України. 2019, т. 29, № 9. С. 32-37.

Citation APA: Kurnytska, M. P., Parkhuts, L. V., \& Horbenko, N. Ye. (2019). The landscape and historic analysis of the park territory of Pomoryany village. Scientific Bulletin of UNFU, 29(9), 32-37. https://doi.org/10.36930/40290905 
Meта дослідження - проаналізувати історичні особливості формування паркової території біля замку в смт Поморяни, провести іiї ландшафтно-просторовий аналіз та дослідити сучасний стан дендрофлори парку.

Основні завдання дослідження - опрацювати архівні матеріали об'єкта, узагальнити композиційно-планувальні особливості призамкової території, проаналізувати об'ємно-просторову, систематичну та вікову структуру насаджень, їх якісний стан.

Наукова новизна дослідження та практична значущцість отриманих результатів. Вперше проведено ретроспективний аналіз паркової території Поморянського замку з питань його об'ємно-просторової та планувальної структури, здійснено дослідження деревостану парку за таксономічним складом, біометрією, віковою структурою та якісним станом, що важливо для розроблення проектів відновлення паркової композиції та адаптації території до сучасних умов функціонування як туристично перспективного об'єкта.

Матеріали і методи дослідження. У роботі користувались історичними та архівними джерелами, здійснювали польові та візуальні обстеження. Подеревну інвентаризацію насаджень проводили згідно з Інструкцією (Instrukcija..., 2001). Видовий склад вищих рослин визначали за довідниками "Дендрофлора України" (Kokhno i in., 2001, 2002). Вік дерев визначено за допомогою ретроспективного аналізу, таблиць ходу росту насаджень (1958) та методики із застосуванням відповідних коефіцієнтів для видів деревних рослин (Parnikoza, 2016), розподіл за віковими категоріями - за розробленою 4-бальною шкалою В. П. Шлапака (Shlapak et al., 2011).

Результати дослідження. Поморянський паркпам'ятка садово-паркового мистецтва XIX ст. місцевого значення, який створено навколо замку в смт Поморяни Золочівського району - пам'ятки архітектури державного значення. На думку Броніслава Заморського, Поморянський замок заклав Миколай Свинка між 13401350 рр. у вигляді дерев'яної фортеці. ÏÏ спорудили на рівному плато півострова, який $з$ трьох боків омивався великою заплавою річки Золота Липа. 3 часом довкола сформувалося поселення Поморяни, яке отримало статус міста і право щотижневих торгів у 1456 р.

3 часом маєтність Поморян перейшла до родини королів Собеських, за яких споруда набула вигляду замку у вигляді чотирикутника із внутрішнім двором (Czołowski, Janusz, 1926). Однак історія парку починається тоді, коли власником Поморян у 1789 р. стає каштелян Еразм Прушинський. Саме він заклав навколо замку парк і збудував теплиці (Zamorski, 1867). Парк було створено у популярному на той час англійському стилі.

Про початкове планування парку можемо мати уявлення із кадастрової карти 1845 р. та австрійської військової карти другого обстеження у 1861-1864 рр. (рис. 1, 2). На карті показані замок із східним та південним крилами, башта, конюшні, млин та інші господарські будівлі (Kadastrova karta, 1845). Навколо замку розплановані паркові доріжки. Хоча на карті детально не відображені зелені насадження та їх точне місце розташування, умовні позначення дають загальну уяву про угруповання насаджень. У південній частині іде чергування більш загущених насаджень (сірий колір) із відкритими галявинами. Велика відкрита галявина влаштована на південь від південного крила замку. У північній частині насадження більш проріджені і також чергуються із відкритими галявинами. Східна частина парку, імовірно, мала фруктовий сад та город, які показані на карті іншими відтінками зеленого кольору (див. рис. 1).

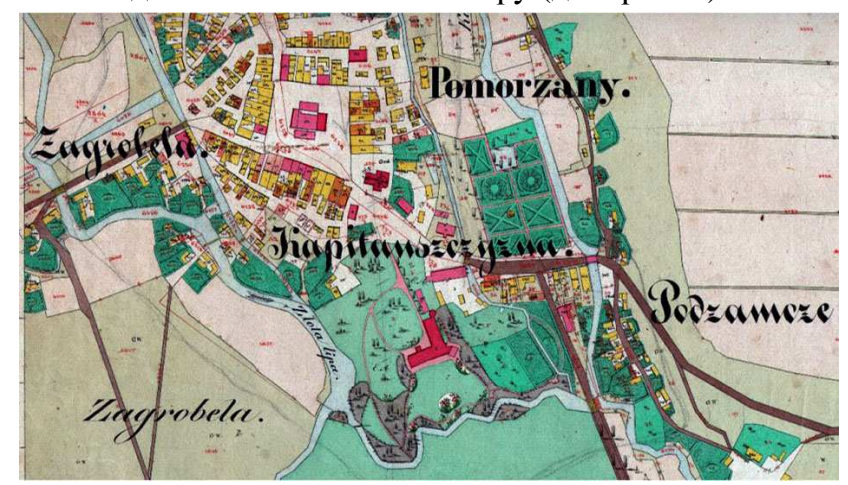

Рис. 1. Центральна частина Поморян: фрагмент кадастрової карти 1845 p. (Kadastrova karta, 1845)

3і східного боку територія замку обмежувалась штучно створеною млинівкою, на якій стояв млин. Південна та західна частини омивалися водами річки Золота Липа. Імовірно, певні зміни у планування призамкової території сталися у другій половині XIX ст. Військова карта імперії Габсбургів відображає дещо інше планування парку (див. рис. 2). Тепер головна алея оперізує по периметру підніжжя пагорба, на якому розташований замок та єднається двома взаємно перпендикулярними внутрішніми алеями, які сходяться до овальної клумби посеред двору (Galicia and Bucovina ...). Тут немає деталей, бо масштаб карти дає змогу лише умовно передати планування, та все ж ідейний задум є зрозумілим.

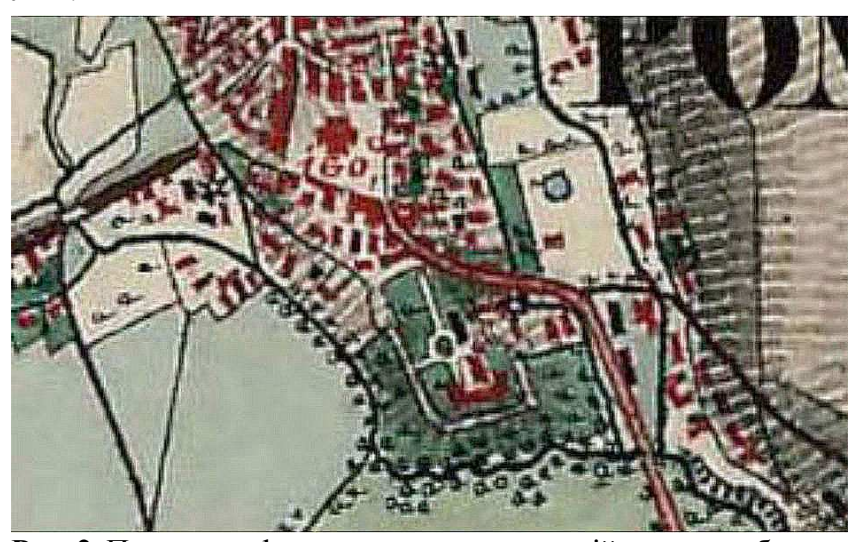

Рис. 2. Поморяни: фрагмент карти другого військового обстеження імперії Габсбургів 1861-1864 pp. (Galicia and Bucovina...)

Вірогідно, що Йосиф Прушинський наприкінці свого життя вніс зміни у доріжкову систему парку, надавши основному плануванню більше регулярного характеру при збереженому пейзажному стилі садово-паркових композицій. Про наявність такого планування до першої третини XX ст. вказують також світлини Поморянського замку та парку, зроблені у 1925 та 1938 pp. (рис. 3). Доповнюють уявлення світлини рис. 4 , де при уважному розгляді бачимо пластику ліній доріжок, які підпорядковані східному замковому крилу та західній частині двору.

Отже, можна припустити, що під час пізнішого перепланування парку використовували прийом поєднання регулярної загальної композиції із пластичними лініями невеликих доріжок, що ув'язувалися зі спорудою замку. 
Велику увагу приділяли трав'яному вкриттю та відкритим просторам, які давали змогу оглядати архітектуру та садово-паркові композиції. Подібні прийоми планування зустрічаються у відомих панських маєтках Галичини, наприклад, у палацово-паркових комплексах Станіслава Бадені у Коропці, братів Гредлів у Сколе, Казимира Бадені у Буську.

У 1879 р. Поморяни та замок переходять у власність родини Потоцьких. Юрій Потоцький до 1939 р. опікувався замком та парком. Із спогадів очевидців дізнаємо- ся, що посеред двору були клумби, в яких зростали троянди, а доріжки парку були влаштовані із подрібненого вапнякового каменю та битої цегли. Можливо, Потоцькі також внесли деякі зміни у садово-паркові композиції. Про це свідчать світлини другої половини 1930-х років, на яких видно висаджені молоді саджанці листяних дерев на території двору (10 faktiv...). Форма клумби уже відрізняється від попередньої.
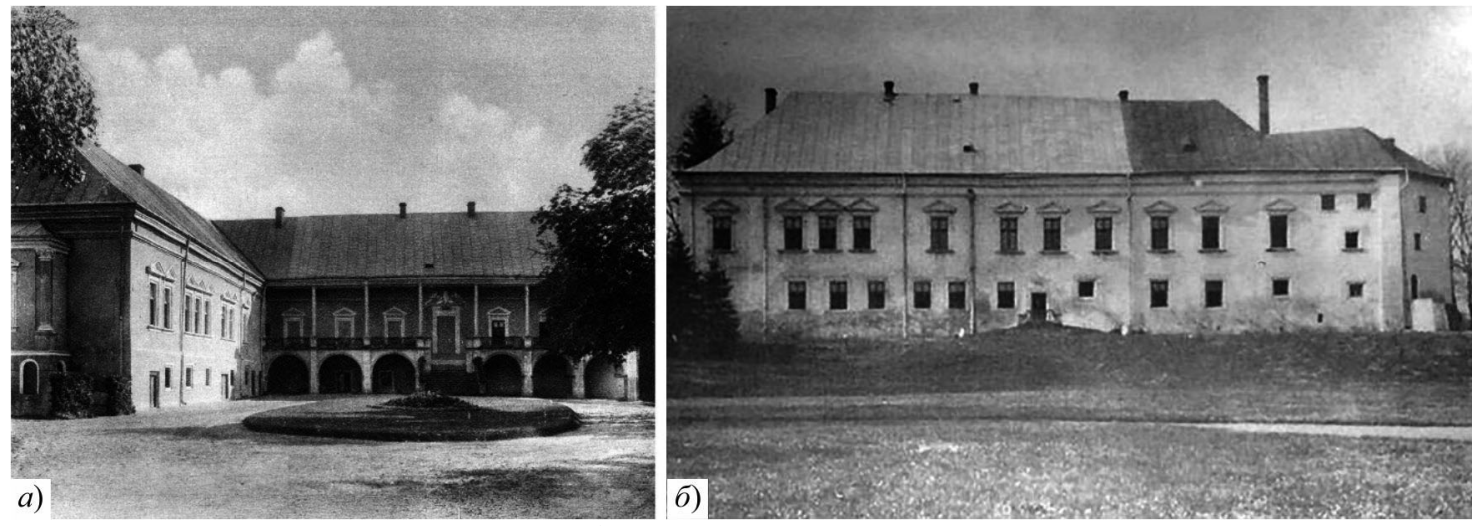

Рис. 3. Двір ( $a$ - Czołowski, Janusz, 1926) та галявина ( 6 - Bukhalo, 2019) Поморянського замку
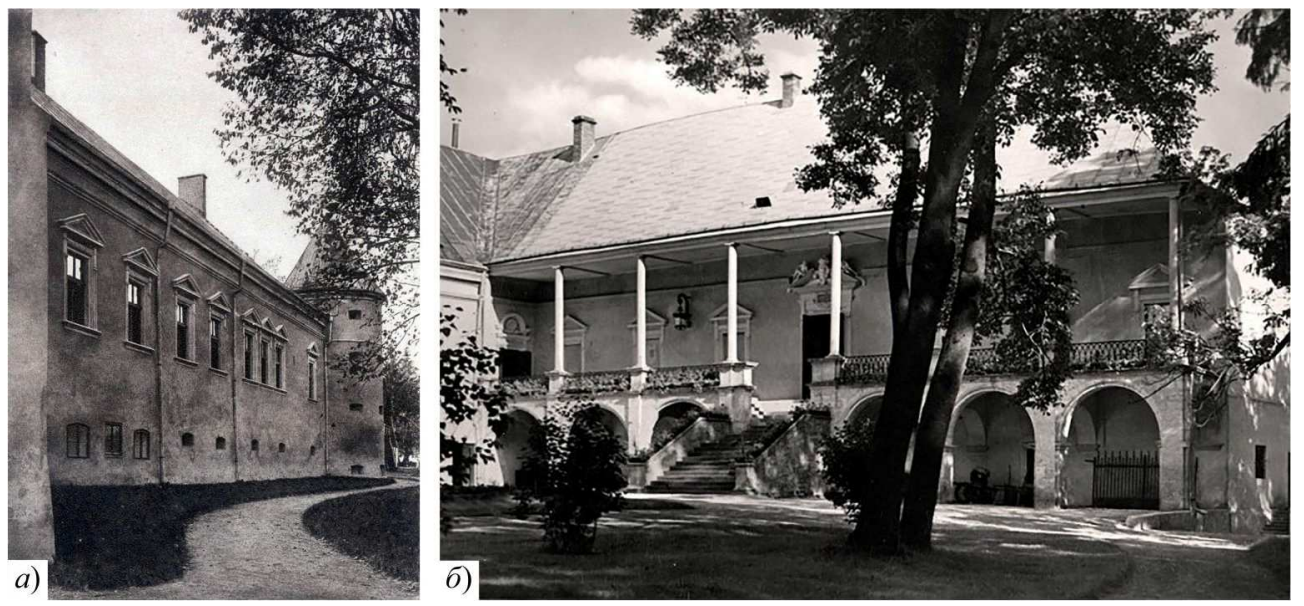

Рис. 4. Східне крило замку ( $a-10$ faktiv $\ldots)$ та двір ( $\sigma$ - Czołowski, Janusz, 1926)

У радянські часи в приміщенні замку були різні установи. Щоб зберегти цілісним Поморянський парк, рішенням виконавчого комітету Львівської обласної ради від 2 жовтня 1970 р. № 634 йому надано статус пам'ятки садово-паркового мистецтва місцевого значення. Парк площею 7 га та приміщення замку передано у відання Поморянського ССПТУ № 36. Через тринадцять років Рада Міністрів Української РСР прийняла постанову від 22.07.1983 № 311 "Про класифікацію і мережу територій і об'єктів природно-заповідного фонду Української РСР", в якій вимагалося впорядкувати мережу природно-заповідного фонду відповідно до прийнятої класифікації. 3 цією метою виконком Львівської обласної ради розробив низку заходів щодо реконструкції пам'яток садово-паркового мистецтва, відповідно до рішення якого від 9 жовтня 1984 р. за № 495 в період 1989-1990 рр. було розроблено проектну документацію реконструкції Поморянського парку та його насаджень, але проект так і не було реалізовано.

Студентські розвідки, які проводили на території пам'ятки у рамках навчальних практик кафедри ландшафтної архітектури, садово-паркового господарства та урбоекології НЛТУ у 2018 р., виявили залишки колишніх земляних укріплень та окремі фрагменти доріжок, які добре збереглися під гумусним нашаруванням землі.

Детальні обстеження стосувались, насамперед, зростаючих насаджень, що важливо для планування подальших реконструктивних заходів збереження і вдосконалення наявного стану призамкової території. У просторовій структурі парку на сьогодні переважає закритий тип, який займає близько $65 \%$ площі. Він представлений досить щільними деревними насадженнями 3 повнотою від 0,6 до 0,8. Розташування їх лише частково збігається 3 даними кадастрових карт (див. рис. 1, 2) на ділянках поблизу млинівок. Відкритою залишається зона подвір'я перед головною будівлею та східна частина парку. Ділянка на південь від замку заповнена рідким деревостаном малоцінних видів (самосів) (рис. 5).

Усього в парку зростає близько 400 дерев, асортимент яких представлений 15 видами, що належать до 11 родів та 8 родин (табл. 1). Переважають у складі деревостану Tilia cordata Mill., Fraxinus excelsior L., Salix alba L. та Acer platanoides L., які, ймовірно, були осно- 
вою паркових насаджень у часи його закладання. Їх розташування припадає на ті зони, які засаджувались під час створення парку (за даними кадастрових карт).

Цікаву інформацію отримано 3 аналізу вікової структури насаджень (табл. 2). Загалом лідирує вікова група 121-150 років, де найбільше представників Tilia cordata (38 екз.) і Fraxinus excelsior L. (17 екз.). Понад $40 \%$ всіх дерев становлять рослини старші за 120 років, що засвідчує їх історичне походження та добру довговічність. Значна частина молодшого покоління представлена малоцінними видами Salix alba L., Populus alba L., Populus nigra L., Populus tremula L.
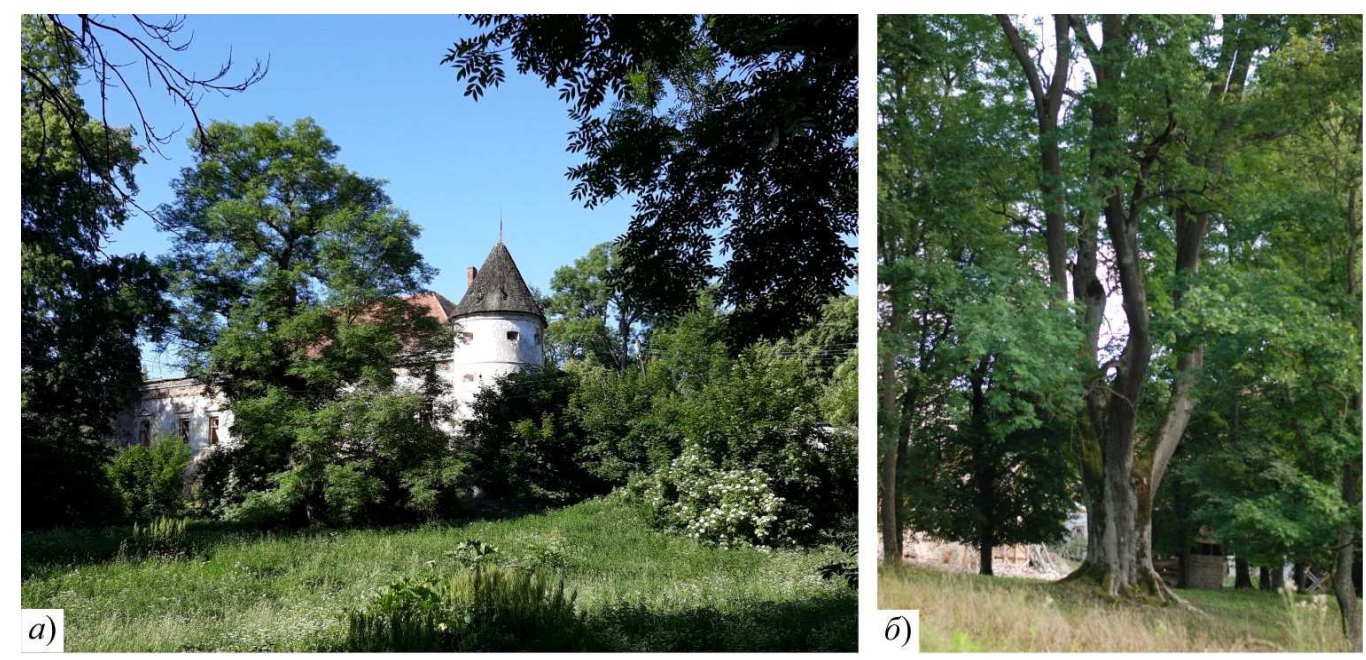

Рис. 5. Фрагменти сучасного вигляду території біля замку (власні світлини)

Табл. 1. Систематична структура насаджень парку

\begin{tabular}{|c|c|c|c|c|}
\hline № $3 / \Pi$ & Назва виду & Частка участі, \% & Рід & Родина \\
\hline 1 & Picea abies L. & 1,77 & Picea & Pinaceae \\
\hline 2 & Betula pendula Roth. & 0,25 & Betula & \\
\hline 3 & Carpinus betulus $\mathrm{L}$. & 0,39 & Carpinus & Betulaceae \\
\hline 4 & Salix alba $\mathrm{L}$. & 3,54 & Salix & \multirow{4}{*}{ Salicaceae } \\
\hline 5 & Populus alba $\mathrm{L}$. & 3,54 & \multirow{3}{*}{ Populus } & \\
\hline 6 & Populus nigra L. & 4,30 & & \\
\hline 7 & Populus tremula L. & 8,10 & & \\
\hline 8 & Prunus domestica L. & 0,25 & \multirow{2}{*}{ Prunus } & \multirow{2}{*}{ Rosaceae } \\
\hline 9 & Prunus padus L. & 0,25 & & \\
\hline 10 & Fraxinus excelsior L. & 21,00 & Fraxinus & Oleaceae \\
\hline 11 & Acer platanoides $\mathrm{L}$. & 10,63 & \multirow{2}{*}{ Acer } & \multirow{3}{*}{ Sapindaceae } \\
\hline 12 & Acer pseudoplatanus L. & 1,77 & & \\
\hline 13 & Aesculus hippocastanum L. & 1,01 & Aesculus & \\
\hline 14 & Tilia cordata Mill. & 30,89 & Tilia & Malvaceae \\
\hline 15 & Ulmus glabra Huds. & 1,26 & Ulmus & Ulmaceae \\
\hline
\end{tabular}

Табл. 2. Розподіл насаджень парку за видовим складом у розрізі груп віку

\begin{tabular}{|c|c|c|c|c|c|c|c|c|c|}
\hline \multirow{2}{*}{$\begin{array}{l}\text { № } \\
\text { 3/ח }\end{array}$} & \multirow{2}{*}{ Назва виду } & \multicolumn{8}{|c|}{ Групи віку, роки } \\
\hline & & $<40$ & $41-60$ & $61-80$ & $81-100$ & $101-120$ & $121-150$ & $151-200$ & $>200$ \\
\hline 1 & Tilia cordata Mill. & 3 & 1 & 18 & 21 & 15 & 38 & 17 & 9 \\
\hline 2 & Fraxinus excelsior L. & & 4 & 6 & 18 & 11 & 17 & 19 & 8 \\
\hline 3 & Salix alba L. & 5 & 7 & 23 & 15 & 6 & 3 & & \\
\hline 4 & Acer platanoides $\mathrm{L}$. & 1 & 6 & 2 & 2 & 12 & 10 & 8 & 1 \\
\hline 5 & Populus tremula L. & 3 & 1 & 6 & 11 & 3 & 8 & & \\
\hline 6 & Populus nigra $\mathrm{L}$. & & & 4 & 2 & 5 & 6 & & \\
\hline 7 & Populus alba $\mathrm{L}$. & 1 & & 3 & 3 & 2 & 5 & & \\
\hline 8 & Acer pseudoplatanus L. & & & & 1 & 4 & 1 & 1 & \\
\hline 9 & Picea abies L. & 3 & & & 4 & & & & \\
\hline 10 & Ulmus glabra Huds. & 2 & & 1 & 1 & & 1 & & \\
\hline 11 & Carpinus betulus L. & 2 & & & & & & & \\
\hline 12 & Aesculus hippocastanum L. & & & 2 & & & 2 & & \\
\hline 13 & Betula pendula Roth. & & & & 1 & & & & \\
\hline 14 & Prunus domestica $\mathrm{L}$. & & & & & & 1 & & \\
\hline 15 & Prunus padus L. & & 1 & & & & & & \\
\hline & Усього: & 20 & 20 & 65 & 79 & 58 & 92 & 45 & 18 \\
\hline & $\%$ & 5,04 & 5,04 & 16,37 & 19,90 & 14,61 & 23,17 & 11,34 & 4,53 \\
\hline
\end{tabular}


Серед старожилів парку виявлено 8 дерев Fraxinus excelsior та 9 особин Tilia cordata, вік яких сягає 200500 років, а окружності стовбура становлять більше 3 м. Особливо варто виділити два дерева цих видів з обхватом стовбура 6,1 м та 5,0 м відповідно, що дає змогу класифікувати їх як дерева-довгожителі з вимогою подальшого заповідання й отримання охоронного статусу.

Природне старіння насаджень, самовільне заростання, зміна природних умов, відсутність догляду не могли не позначитись на санітарному та декоративному станах деревних рослин парку. 17,7 \% дерев перебувають у доброму якісному стані, але це, передусім, пояснюють молодшим віком рослин. Більшість дерев (74,4\%) мають задовільний якісний стан, який проявляється наявними поодинокими сухими гілками, тріщинами та дуплами на стовбурі, плодовими тілами грибів. Здебільшого такі проблеми стосуються вікових Tilia та Fraxinus, а також недовговічних Salix і Populus.

Висновки. Підсумовуючи, можна виділити такі особливості території замку в смт Поморяни:

- в історичних документах міститься лише часткова інформація щодо часу створення та планувально-просторових особливостей паркової території біля замку в Поморянах;

• планувальна структура об'єкта ні періоду закладання, ні періоду розквіту практично не збереглася;

- доріжкова мережа парку фактично відсутня, окрім частини центральної алеї та декількох периферійних доріжок, покриття яких заховане під гумусним нашаруванням землі;

• спостережено незначну подібність сучасної об'ємно-просторової структури насаджень деяким періодам функціонування об'єкта;

- деревостан парку представлений 15 видами, що належать до 11 родів та 8 родин; більшість дерев $(74,4 \%)$ мають задовільний якісний стан;

- у насадженнях центральної частини виявлено вікові дерева, вік яких збігається з часом формування основних композицій парку. Значна присутність у деревостані малоцінних і недовговічних Salix, Populus, Prunus свідчить про їх природне походження (самосів), що не відповідає стильовим особливостям композиції об'єкта періоду його розквіту;

- серед багатовікових виявлено два дерева-довгожителі з відповідною історичною та науковою цінністю.

Результати аналізу історичних та польових досліджень свідчать про наявність значних проблем з усіма елементами території Поморянського замку та прилеглої паркової території. Цінність таких об'єктів й інтерес науковців, громади, суспільства є безумовними, але їх відновлення потребує як подальших історико-архівних, так і натурних досліджень, а надалі великих капіталовкладень.

\section{References}

Bucovina. (2019). Galicia and Bucovina (1861-1864) - Second military survey of the Habsburg Empire. Retrieved from: https://mapire.eu/en/map/europe-19century-secondsurvey. (Data of appeal: 29.02.2019).

Bukhalo, O. (2019). Yak u Pomorianskomu zamku pravyly korol, hestapivtsi ta uchni PTU. Retrieved from: https://www.bbc. com/ukrainian/blogs-42144003. (Data of appeal: 29.02.2019). [In Ukrainian].

Czołowski, A., \& Janusz, B. (1926). Przeszłość i zabytki województwa tarno-polskiego. Tarnopol: Nakładem Powiatowej Organizacji Narodowej, $99 \mathrm{p}$.

Denysova, H. V. (2015). Fitotsenotychna struktura palatsovo-parkovykh kompleksiv Zakhidnoho Lisostepu ta shliakhy yii optymi- zatsii. Abstract of candidate dissertation for agricultural sciences. (06.03.01 - Forest crops and Phytomelioration). Lviv: National Forestry University of Ukraine, $20 \mathrm{p}$. [In Ukrainian].

Derevni porody. (1958). Tablytsi khodu rostu i tovarnosti nasadzhen derevnykh porid Ukrainy. Kyiv: Derzhsilskohospvydav, 56 p. [In Ukrainian].

Kadastrova karta 1845 roku. (2019). Tsentralnyi derzhavnyi istorychnyi arkhiv Ukrainy u m. Lvovi. F. 186, op. 6, spr. 983, ark. 18.

Klymenko, Yu. O. (2012). Ekoloho-biolohichni osnovy vidnovlennia starovynnykh parkiv Polissia ta Lisostepu Ukrainy. Doctoral dissertation for agricultural sciences. Kyiv: National Academy of Sciences of Ukraine, National Grishko Botanical Garden, 413 p. [In Ukrainian].

Klymenko, Yu. O., \& Kuznetcov, S. I. (2015). Zahalne parkoznavstvo (istorychni, bioloho-ekolohichni, landshaftno-lisivnychi pidkhody ta metody). Kyiv: TsP "Komprynt", 415 p. [In Ukrainian].

Kokhno, M. A., et al. (2001). Dendroflora Ukrainy. Dykorosli ta kultyvovani dereva y kushchi. Holonasinni. Kyiv: Higher school, 207 p. [In Ukrainian].

Kokhno, M. A., et al. (2002). Dendroflora Ukrainy. Dykorosli ta kultyvovani dereva i kushchi. Pokrytonasinni. Kyiv: Fitosotsiotsentr, 448 p. [In Ukrainian].

Ławniczak, Gr. (2014). Analiza przestrzenno-historyczna założenia pałacowo-parkowego w Żydowie gm. Rokietnica, pow. poznański. Wartości zabytkowe rewaloryzowanego obiektu uzasadnieniem wniosku o sporzadzenie planu przestrzennego miejscowości. Teka Kom. Arch. Urb. Stud. Krajobr. - OL PAN, 2014, X/4, 48-62. [In Polish].

Michałowski, A. (2010). Rewaloryzacja ogrodu Jana Klemensa Branickiego w Białymstoku na tle działań konserwatorskich w ogrodach historycznych Europy, [w:] Parki i ogrody zabytkowe, ochrona i konserwacja, Ogród Branickich w Biatymstoku, historia rewaloryzacji, Białystok 2010. [In Polish].

Mitkowska, A. (2012). Rozważania o wartościowaniu ogrodów zabytkowych dla ich ochrony i konserwacji. In: Wartościowanie $w$ ochronie i konserwacji zabytków, (Ed.) B. Szmygin, Wydawnictwo Politechniki Lubelskiej, PKN ICOMOS, Lublin 2012, 121-134. [In Polish].

Moroz, P. I. (2006). Rekonstruktsiia zanedbanykh parkiv yak zasib pokrashchennia landshaftnykh ta estetychnykh yakostei yikh obiektiv. Starovynni parky i botanichni sady - naukovi tsentry zberezhennia bioriznomanittia ta okhorona istoryko-kulturnoi spadshchyny: Materials of the International Scientific Conference, (pp. 357-362). Kyiv: Akademperiodyka. [In Ukrainian].

Orlovskyi, V. K. (2006). Inventaryzatsiia, yak instrument vidtvorennia starovynnykh parkiv. Starovynni parky i botanichni sady - naukovi tsentry zberezhennia bioriznomanittia ta okhorony istorykokulturnoi spadshchyny: Materials of the International Scientific Conference, (pp. 364-366). Kyiv: Akademperiodyka. [In Ukrainian].

Parnikoza, I. Iu. (2016). Kyivski ostrovy ta pryberezhni urochyshcha na Dnipri - pohliad kriz viky. Retrieved from: https://www.myslenedrevo.com.ua/uk/Sci/Kyiv/Islands.html.

Shlapak, V. P., Muzyka, H. I., Vitenko, V. A., \& Marno, L. I. (2011). The biometric characterictics of fage-long woody plants in the Dendrological Park "Sofiyivka" end category distribution of them. Scientific Bulletin of UNFU, 21(5), 8-15. [In Ukrainian].

Sosnova, N. S. (2003). Arkhitekturno-landshaftnyi uklad sadybno-parkovykh kompleksiv Halychyny (kintsia XVIII - pochatku XX stolit). Abstract of Candidate Dissertation for Architectural Sciences (18.00.01 - Architecture theory, restoration of architectural monuments). Lviv: NU "Lvivska politekhnika", 20 p. [In Ukrainian].

Zamok. (2019). 10 faktiv pro Pomorianskyi zamok (video). Retrieved from: https://photo-lviv.in.ua/10-faktiv-pro-pomoryanskyj-zamokvideo. [In Ukrainian].

Zamorski, B. (1867). Kronika pomorzańska wedtug źródel miejscowych opwiedziana. Lwów, 171 p.

Zeleni nasadzhenia. (2001). Instrukcija z tehnichnoi inventaryzacii zelenyh nasadzhen u mistah ta selyshhah miskogo typu Ukrainy. Nakaz Derzhkomitetu budivnyctva, arhitektury ta zhytlovoi polityky Ukrainy № 226 vid 24.12.2001 r. Retrieved from: https://zakon4.rada.gov.ua/laws/show/z0182-02. [In Ukrainian]. 


\section{THE LANDSCAPE AND HISTORIC ANALYSIS OF THE PARK TERRITORY} OF POMORYANY VILLAGE

The territories of palace and park complexes in Ukraine are largely neglected, but historically and culturally they deserve to be preserved and restored. Therefore, comprehensive research on both the architectural and park elements of these sites is needed and expedient. Based of archival documents and through inventory field surveys, the analysis of the planning and spatial structure of the park near the castle in Pomorians village in Lviv region was carried out in the work. Conclusions about the stages of formation of the park composition are made, as well as accounting and analysis of existing plantations depending on dendrochemical composition, age, biometric indicators and quality status. According to cadastral maps of the mid-19th century and photos of the time, the initial planning of the park was of a landscape nature, dominated by wavy paths. There was an alternation of thickened groups of trees with open glades, and the possible location of the orchard and vegetable garden was discovered. Subsequently, regular forms were added to the composition, especially in the ground floor. Much attention was then paid to flower decoration, planting of young trees. Unfortunately, the planning structure of the object was neither preserved nor flourished, and historical sources can give only an approximate idea of the spatial planning features of the territory. Now the park near the castle is dominated by a closed plantation with a density of $0.6-0.8$, which occupies about $65 \%$ of the area of greening. About 400 trees belonging to 15 species grow there. It is dominated by Tilia cordata Mill., Fraxinus excelsior L. and Acer platanoides L., which form the largest age group of more than 120 years, coinciding with the period and zones of laying of the main plantations of the park. In addition, the Fraxinus excelsior and Tilia cordata were cut with a trunk girth of $6.1 \mathrm{~m}$ and $5.0 \mathrm{~m}$, respectively, which allows them to be classified as long-lived trees and give them protection status. A considerable part of the younger generation is represented by low-value species Salix alba L., Populus alba L., Populus nigra L., Populus tremula L. More than $70 \%$ of the surveyed trees are in good quality, reach their maximum age and have available hollows, cracks, fruiting bodies, mushrooms, and dried branches. In developing projects for the reconstruction of the existing plantation of the park, the main attention should be paid to the preservation of old trees, the culling of low-value and short-lived species, the use of appropriate agrotechnological techniques for increasing the viability of woody plants, the planning of landscape and decorative techniques for the formation of park compositions.

Keywords: castle territory; terrain; composition; age structure; age structure. 